\title{
DIARE DAN ASUPAN ZAT GIZI (PROTEIN, VITAMIN A, ZINC, KALSIUM, BESI) TERHADAP KEJADIAN STUNTING PADA ANAK UMUR 2 - 5 TAHUN
}

\author{
Irza N. Ranti ${ }^{1}$, Meildy E. Pascoal ${ }^{1}$. Mizzy Cristania Wowor ${ }^{2}$ \\ Jurusan Gizi Politeknik Kesehatan Kemenkes Manado \\ email korespondensi: irzaranti1@gmail.com
}

\begin{abstract}
Based on the latest Riskesdas data in 2013, the prevalence of stunting in Kotamobagu City was $38.1 \%$. Poor hygiene practices can cause toddlers to develop diarrhea, which in turn can cause children to lose nutrients that are important for growth. This study aims to determine the relationship of diarrhea and nutrient intake to the incidence of stunting in children under five in the Gogagoman Community Health Center. This type of observational analytic study with cross sectional design. The number of samples as many as 41 toddlers taken with nonprobability techniques with purposive sampling method. The results showed that $70.7 \%$ of children have had diarrhea, no relationship between the intake of Protein, Vitamin A, Iron on the incidence of stunting. As for Diarrhea, Zinc, and Calcium intake have a significant relationship, intake of vitamin A, Zinc, potassium, and iron intake less than standard. Conclusion, there is a relationship between diarrhea, zinc intake, and calcium intake on the incidence of stunting.
\end{abstract}

Keywords: stunting; Diarrhea; Nutrient

Stunting menggambarkan status gizi kurang, yang bersifat kronik pada masa pertumbuhan dan perkembangan sejak awal kehidupan atau pada 1000 Hari Pertama Kehidupan. Keadaan ini dipresentasikan dengan nilai $z$-score tinggi badan menurut umur (TB/U) kurang dari -2 standar deviasi (SD) berdasarkan standar pertumbuhan menurut WHO (WHO, 2010). Stunting disebabkan oleh faktor multi dimensi dan tidak hanya disebabkan oleh faktor gizi buruk yang dialami oleh ibu saat hamil maupun anak balita. Kejadian gagal tumbuh yang terjadi pada usia balita akan berlanjut ke usia berikutnya. Besar kemungkinan ketika mereka menginjak usia 19 tahun, maka tinggi badan optimal tidak tercapai. Mereka akan menjadi manusia dewasa yang pendek dengan keterbatasan untuk berproduktivitas secara optimal (Trihono dkk, 2015).

Secara global pada tahun 2016, sebanyak 22,9\% atau 154.800 .000 anak di bawah usia 5 tahun menderita stunting (WHO). Sedangkan dari data nasional, berdasarkan data Pemantauan Status Gizi (PSG) pada tiga tahun terakhir, persentasi balita Stunting di Provinsi Sulawesi Utara pada tahun 2015 sebanyak 22,2\%. Sedangkan pada tahun 2016 sebanyak $21,2 \%$, dan pada tahun 2017 terjadi peningkatan, yaitu sebanyak 31,4\%. Sedangkan berdasarkan data Riskesdas tahun 2013, persentasi anak balita Indonesia yang mengalami stunting sebanyak $37,2 \%$. Hasil Riset Kesehatan Dasar 2013 di Provinsi Sulawesi Utara mencatat prevalensi stunting adalah $34,8 \%$. Presentase tersebut dengan pembagian kategori pendek 17,8\% dan kategori sangat pendek adalah $17,0 \%$. Sedangkan untuk Kota Kotamobagu, prevalensi stunting adalah 38,1\% (Balitbangkes, 2013). Stunting pada anak merupakan dampak yang bersifat kronis dari konsumsi makanan berkualitas rendah yang terus menerus dan didukung oleh penyakit infeksi dan masalah lingkungan. praktik higiene yang buruk dapat menyebabkan balita terserang penyakit diare yang nantinya dapat menyebabkan anak kehilangan zat-zat gizi yang penting bagi pertumbuhan

Status gizi khususnya, berkaitan erat dengan asupan zat gizi dan penyakit infeksi. Penyakit infeksi dan asupan zat gizi merupakan faktor penyebab langsung terhadap masalah gizi ataupun 
status gizi anak. Asupan zat gizi dan penyakit infeksi saat berdiri sendiri dapat mempengaruhi pertumbuhan, kedua faktor ini dapat saling mempengaruhi dan memberikan efek lebih buruk apabila bersamaan. Asupan zat gizi yang tidak seimbang dapat mengganggu kerja imun tubuh yang meningkatkan resiko infeksi. Di sisi lain, tubuh yang mengalami infeksi membutuhkan asupan zat gizi yang lebih tinggi untuk proses pemulihan, dan apabila tidak terpenuhi maka akan memperburuk kondisi tubuh yang nantinya mempengaruhi status gizi seseorang (Fikawati dkk, 2017). Berdasarkan data Riskesdas terakhir yakni tahun 2013, kejadian diare pada balita di Provinsi Sulawesi Utara adalah 4,2\%. Dan untuk Kota Kotamobagu sendiri, sebanyak 5\% (Riskesdas, 2013). Karena tingginya kejadian diare dan tingginya angka stunting maka mendorong penulis utk meneliti hubungan diare dan asupan zat gizi (protein, vitamin a, zinc,kalsium, besi) terhadap kejadian stunting pada anak balita.

\section{METODE}

Penelitian ini merupakan penelitian observasional analitik dengan rancangan cross sectional study. Dalam penelitian ini terdapat dua variabel antara lain variabel independen dan variabel dependent. Variabel independent yaitu penyakit infeksi (diare) dan asupan zat gizi (Protein, Vitamin A, Zinc, Kalsium, Besi). Sedangkan variabel dependent yaitu stunting. Populasi dalam penelitian ini yaitu semua anak usia 2-5 tahun yang ada di wilayah kerja Puskesmas Gogagoman Kota Kotamobagu. Sampel dalam penelitian ini sebanyak 41 anak yang diambil menggunakan teknik purposive sampling yaitu pengambilan sampel dengan melihat populasi yang memenuhi kriteria inklusi dan ekslusi. Kriteria inklusi antara lain anak yang berumur 2-5 tahun, didampingi orangtua (ibu/ pengganti ibu) saat penelitian berlangsung, orangtua bisa membaca dan menulis, orangtua dapat berkomunikasi dalam keadaan sadar, bersedia menjadi responden dalam penelitian. Sedangkan untuk kriteria ekslusi yaitu anak mengalami gangguan mental ataupun cacat fisik, anak sakit dan sedang dirawat di fasilitas kesehatan. Sampel akhirnya dapat dikumpulkan berdasarkan kriteria inklusi (41 orang)

Dalam penelitian ini data yang dikumpulkan adalah data primer yaitu asupan zat gizi (Protein, Vitamin A, Zinc, Kalsium, Besi), data antropometri, data identitas dan kesehatan anak yang diperoleh melalui wawancara menggunakan kuesioner, pengukuran tinggi badan dan formulir Food Frequency Quesionnaire (FFQ) semi kuantitatif. Dan data sekunder yaitu gambaran umum Puskesmas Gogagoman, diperoleh melalui profil Puskesmas. Instrument yang digunakan dalam penelitian ini yaitu formulir FFQ semi kuantitatif, microtoise, dan kuesioner. mengenai kejadian diare pada anak usia 2-5 tahun.

Pengolahan dan analisis data dilakukan dengan analisis univariat dan bivariate. Analisis untuk univariat disajikan dalam tabel distribusi frekuensi untuk memperoleh informasi secara umum mengenai karakteristik sampel dan responden, status gizi, riwayat diare dan asupan zat gizi. Analisis bivariate menggunakan uji Fisher exact untuk melihat hubungan antara variabel kejadian diare,dan asupan zat gizi protein,vitamin a, zinc, kalsium dan besi terhadap kejadian stunting . Jika $\rho$ value $<0,05$ maka $H_{a}$ diterima dan $H_{0}$ ditolak, jika >0,05 maka $H_{0}$ diterima dan $H_{a}$ ditolak.

\section{HASIL}

Berdasarkan hasil penelitian diketahui bahwa karakteristik responden menunjukkan bahwa dari 41 orang responden, kelompok umur terbanyak pada umur 26-31 tahun sebanyak 36,6\% (15 orang), Selanjutnya tingkat pendidikan, perguruan tinggi hanya sebanyak $12,1 \%$ (5 orang), dan yang berpendidikan persentase tertinggi berada pada tingkat pendidikan SMP sebanyak 41,5\% (17 orang), sementara untuk pekerjaan responden sebagian besar adalah Ibu Rumah Tangga sebanyak 95,1\% (39 orang). . Karakteristik sampel menunjukkan bahwa dari 41 orang anak, 
sebagian besar sampel berada pada usia 36-47 bulan sebanyak 46,3\% (19 orang), berdasarkan jenis kelamin, sebagian besar adalah laki-laki yaitu 58,5\% (24 orang).

Riwayat status gizi dan riwayat diare sama di mana dari 41 anak yang mengalami stunting $70.7 \%$ (29 anak) dan normal $29.3 \%$ (12 anak). Untuk asupan protein yang baik ada $92.7 \%$ ( 38 anak), kurang 7.3\% (3 anak), asupan Vitamin A yang baik 63.4\% ( 26 anak) dan kurang 36.6\% ( 15 anak), asupan Zinc baik 41.5\% ( 17 anak), kurang $58.5 \%$ ( 24 anak), asupan Kalsium baik $24.4 \%$ ( 10 anak), kurang 75.6\% ( 31 anak) dan untuk asupan Besi baik 61.6\% (25 anak), kurang $39 \%$ ( 16 anak).

Tabel 1. Hubungan Diare dengan Kejadian Stunting

\begin{tabular}{cccccccc}
\hline \multirow{2}{*}{ Riwayat Diare } & \multicolumn{3}{c}{ Status Gizi (TB/ U) } & & \multicolumn{2}{c}{ Total } & \\
\cline { 2 - 6 } & \multicolumn{2}{c}{ Stunting } & & Normal & & \\
\cline { 2 - 6 } & $\mathrm{n}$ & $\%$ & $\mathrm{n}$ & $\%$ & $\mathrm{n}$ & $\%$ \\
\hline Diare & 24 & 58.5 & 5 & 12.2 & 29 & 70.7 \\
Tidak Diare & 5 & 12.2 & 7 & 17.1 & 12 & 29.3 & 0,02 \\
\hline Jumlah & 29 & 70.7 & 12 & 29.3 & 41 & 100 & \\
\hline
\end{tabular}

Hasil analisis uji Fisher exact test menunjukkan bahwa terdapat hubungan yang bermakna antara diare dengan kejadian stunting pada anak balita di wilayah kerja Puskesmas Gogagoman dengan nilai $\rho 0.00<0,02$. Hasil penelitian menunjukkan bahwa dari 41 sampel terdapat 58.5\% orang anak balita (stunting) yang mengalami diare dan $12.2 \%$ orang balita (stunting) tidak mengalami diare, sedangkan $12.2 \%$ orang anak balita (normal) yang pernah mengalami diare dan $17 . \%$ orang anak balita (normal) yang tidak pernah mengalami diare.

Tabel 2. Hubungan Asupan Protein dengan Kejadian Stunting

\begin{tabular}{|c|c|c|c|c|c|c|c|}
\hline \multirow{3}{*}{ Asupan } & \multicolumn{4}{|c|}{ Status Gizi (TB/ U) } & \multirow{2}{*}{\multicolumn{2}{|c|}{ Total }} & \multirow{3}{*}{$\rho$} \\
\hline & \multicolumn{2}{|c|}{ Stunting } & \multicolumn{2}{|r|}{ Normal } & & & \\
\hline & $\mathrm{n}$ & $\%$ & $\mathrm{n}$ & $\%$ & $\mathrm{n}$ & $\%$ & \\
\hline Baik & 26 & 63.4 & 12 & 29.3 & 38 & 92.7 & \\
\hline Kurang & 3 & 7.3 & 0 & 0 & 3 & 7.3 & 0,02 \\
\hline Jumlah & 29 & 70.7 & 12 & 29.3 & 41 & 100 & \\
\hline
\end{tabular}

Hasil analisis uji Fisher's Exact test menunjukkan bahwa tidak terdapat hubungan yang bermakna antara asupan protein dengan kejadian stunting pada balita di wilayah kerja Puskesmas Gogagoman dengan nilai $\rho>0,05$. Hubungan asupan protein dengan kejadian stunting menunjukkan sebanyak $63.4 \%$ anak balita dengan status gizi stunting memiliki asupan protein yang baik, dan $7.3 \%$ anak balita dengan status gizi stunting memiliki asupan protein yang kurang. Sementara itu pada anak balita dengan status gizi normal semuanya $29.3 \%$ memiliki asupan protein yang baik. 
Tabel 3. Hubungan Asupan Vitamin A dengan Kejadian Stunting

\begin{tabular}{|c|c|c|c|c|c|c|c|}
\hline \multirow{3}{*}{ Asupan } & \multicolumn{4}{|c|}{ Status Gizi (TB/ U) } & \multirow{2}{*}{\multicolumn{2}{|c|}{ Total }} & \multirow{3}{*}{$\rho$} \\
\hline & \multicolumn{2}{|c|}{ Stunting } & \multicolumn{2}{|r|}{ Normal } & & & \\
\hline & $\mathrm{n}$ & $\%$ & $\mathrm{n}$ & $\%$ & $\mathrm{n}$ & $\%$ & \\
\hline Baik & 18 & 43.9 & 8 & 19.5 & 26 & 63.4 & \\
\hline Kurang & 11 & 26.8 & 4 & 9.8 & 15 & 36.6 & 0,02 \\
\hline Jumlah & 29 & 70.7 & 12 & 29.3 & 41 & 100 & \\
\hline
\end{tabular}

Hasil analisis uji Fisher's exact test menunjukkan bahwa tidak terdapat hubungan yang bermakna antara asupan Vitamin A dengan kejadian stunting pada balita di wilayah kerja Puskesmas Gogagoman dengan nilai $\rho>0,05$. Data penelitian menunjukkan sebagian besar responden memiliki asupan vitamin a yang baik, bahkan cenderung melebihi anjuran angka kecukupan gizi, hal ini dapat dilihat dari tingkat asupan Vitamin A yang sebagian besar lebih dari $80 \%$ sebanyak $63.4 \%$.

Tabel 4. Hubungan Asupan Zinc dengan Kejadian Stunting

\begin{tabular}{cccccccc}
\hline \multirow{2}{*}{ Asupan } & \multicolumn{4}{c}{ Status Gizi (TB/ U) } & \multicolumn{2}{c}{ Total } & $\rho$ \\
\cline { 2 - 5 } & \multicolumn{2}{c}{ Stunting } & \multicolumn{3}{c}{ Normal } & & \\
\cline { 2 - 6 } & $\mathrm{n}$ & $\%$ & $\mathrm{n}$ & $\%$ & $\mathrm{n}$ & $\%$ & \\
\hline Baik & 9 & 21.0 & 8 & 19.5 & 17 & 41.5 & \\
Kurang & 20 & 48.8 & 4 & 9.8 & 24 & 58.5 & \multirow{2}{*}{0,02} \\
\hline Jumlah & 29 & 69.8 & 12 & 29.3 & 41 & 100 & \\
\hline
\end{tabular}

Berdasarkan analisis uji Fisher's Exact test menunjukkan bahwa terdapat hubungan yang bermakna antara asupan zinc dengan kejadian stunting pada anak balita di wilayah Kerja Puskesmas Gogagoman dengan nilai $\rho<0,05$.

Tabel 5. Hubungan Asupan Kalsium dengan Kejadian Stunting

\begin{tabular}{|c|c|c|c|c|c|c|c|}
\hline \multirow{3}{*}{ Asupan } & \multicolumn{4}{|c|}{ Status Gizi (TB/ U) } & \multirow{2}{*}{\multicolumn{2}{|c|}{ Total }} & \multirow{3}{*}{$\rho$} \\
\hline & \multicolumn{2}{|c|}{ Stunting } & \multicolumn{2}{|c|}{ Normal } & & & \\
\hline & $\mathrm{n}$ & $\%$ & $n$ & $\%$ & $n$ & $\%$ & \\
\hline Baik & 10 & 24.4 & 8 & 19.5 & 18 & 43.9 & \\
\hline Kurang & 19 & 46.3 & 4 & 9.8 & 23 & 56.1 & 0,02 \\
\hline Jumlah & 29 & 70.7 & 12 & 29.3 & 41 & 100 & \\
\hline
\end{tabular}


Tabel 6. Hubungan Asupan Besi dengan Kejadian Stunting

\begin{tabular}{cccccccc}
\hline \multirow{2}{*}{ Asupan } & \multicolumn{4}{c}{ Status Gizi (TB/ U) } & \multicolumn{2}{c}{ Total } & $\rho$ \\
\cline { 2 - 5 } & \multicolumn{2}{c}{ Stunting } & \multicolumn{3}{c}{ Normal } & & \\
\cline { 2 - 6 } & $\mathrm{n}$ & $\%$ & $\mathrm{n}$ & $\%$ & $\mathrm{n}$ & $\%$ & \\
\hline Baik & 18 & 43.9 & 7 & 17.1 & 25 & 61.0 & \\
Kurang & 11 & 26.9 & 5 & 12.2 & 16 & 39.0 & \multirow{2}{*}{0,02} \\
\hline Jumlah & 29 & 70.8 & 12 & 29.3 & 41 & 100 & \\
\hline
\end{tabular}

\section{PEMBAHASAN}

Menurut Adriani dan Wirjatmadi (2014) diare merupakan salah satu dari sekian banyak penyakit infeksi yang dapat menjadi penyebab terjadinya masalah gizi salah satunya yaitu stunting. Hasil penelitian ini sejalan dengan penelitian yang dilakukan oleh Nindya \& Desyanti (2017), dimana dalam penelitiannya menunjukkan bahwa sebagian besar balita pada kelompok stunting mengalami kejadian diare yang sering, sedangkan pada kelompok tidak stunting sebagian besar jarang mengalami diare. Hasil ini berbeda dengan yang dilakukan oleh Purba,dkk (2019) dimana tidak ada hubungan riwayat penyakit diare dengan kejadian dan tidak ada hubungan riwayat pemberian asi eksklusif dengan terjadinya stunting. Hal yang sama juga dilakukan oleh Fatimah dan Wirjatmadi (2018) yang menunjukkan bahwa faktor penyakit infeksi (diare) tidak ada hubungan terhadap kejadian stunting. Begitupula dengan hasil penelitian yang dilakukan oleh Hariyati, dkk (2016) yang menemukan hasil bahwa tidak ada hubungannya antara kejadian stunting dengan riwayat penyakit infeksi yang pernah diderita anak balita.

Berbeda dengan penelitian yang dilakukan Hariyati, dkk (2016) terhadap balita usia 2559 bulan di Wilayah Kerja Puskesmas Kalisat Kabupaten Jember. Dari hasil penelitiannya menunjukkan bahwa ada hubungan antara tingkat konsumsi protein dengan kejadian stunting. Hasil penelitian menunjukkan bahwa sebagian besar responden memiliki asupan protein yang baik sesuai dengan angka kecukupan gizi (AKG) yang dianjurkan.

Tidak adanya hubungan yang bermakna antara asupan protein dengan kejadian stunting karena dari hasil wawancara yang dilakukan dengan responden berdasarkan FFQ menunjukkan kebiasaan sampel yang mengonsumsi asupan sumber protein yang beragam seperti telur ayam, ikan, daging ayam, daging sapi, tahu, tempe, selain itu beberapa anak juga mengonsumsi susu minimal 1x/hari. Hasil penelitian ini sejalan dengan penelitian yang dilakukan Eko Setiawan dkk (2018) yang menunjukkan bahwa tidak adanya hubungan yang signifikan antara asupan protein dengan kejadian stunting. Hasil tersebut juga didukung dengan penelitian yang dilakukan Desy Kumaladewi dkk (2015) terhadap anak usia baru sekolah di Kelurahan Candirejo yang menunjukkan bahwa tidak adanya hubungan yang signifikan antara asupan protein dengan kejadian stunting.

Tidak adanya hubungan yang bermakna antara asupan vitamin a dengan kejadian stunting karena dari hasil wawancara yang dilakukan dengan responden berdasarkan FFQ menunjukkan kebiasaan sampel yang mengonsumsi sumber sumber Vitamin A berupa telur, susu. Dan juga karoten, yaitu sayur yang berwarna hijau tua seperti kangkung, daun singkong, buncis dan kacang panjang, serta buah-buahan yang mengandung karoten seperti papaya dan jeruk. Hasil penelitian ini sejalan dengan penelitian yang dilakukan Desy Kumaladewi, dkk (2015) terhadap anak usia baru sekolah di Kelurahan Candirejo yang menunjukkan bahwa tidak adanya hubungan yang signifikan antara asupan Vitamin A dengan kejadian stunting. Berbeda dengan hasil penelitian yang dilakukan Fatimah dan Wirjatmadi (2018) yang menunjukkan bahwa adanya 
hubungan antara asupan vitamin a dengan kejadian stunting, dikarenakan anak yang stunting tingkat asupan vitamin a cenderung deficit dibandingkan anak balita yang non stunting.

Vitamin A merupakan salah satu vitamin larut lemak yang disimpan dalam hati dan jaringan adipose apabila tidak digunakan oleh tubuh (Almatsier, 2009). Vitamin A memiliki beberapa fungsi yang sangat penting bagi tubuh manusia, diantaranya: sebagai daya penglihatan malam dengan membentuk pigmen retina yang disebut rhodopsin, menjaga keutuhan jaringan epitel dan mukosa yang sehat, berperan dalam reproduksi khususnya ibu hamil dan menyusui, pencegahan kanker dan jantung, dan membantu mengoptimalkan pertumbuhan tulang dan gigi yang normal. Untuk itu kekurangan Vitamin A dapat menyebabkan terjadinya gangguan pertumbuhan (Mardalena, 2017). Kebutuhan Vitamin A berbeda-beda, berdasarkan kebutuhan vitamin a untuk anak balita dibedakan menurut dua golongan umur. Untuk anak usia 1-3 tahun, kebutuhan Vitamin A yaitu 400 mcg. Dan untuk anak usia 4-6 tahun, kebutuhan Vitamin A yaitu 450 mcg (AKG, 2013).

Vitamin A terdapat dalam pangan hewani, sedangkan karoten terutama di dalam pangan nabati. Sumber Vitamin A antara lain: hati, kuning telur, susu (dalam lemaknya), dan mentega. Margarin biasanya diperkaya dengan Vitamin A. Karena Vitamin A tidak berwarna, warna kuning dalam kuning telur adalah karoten yang tidak diubah menjadi Vitamin A. Minyak hati ikan digunakan sebagai sumber Vitamin A yang diberikan untuk keperluan penyembuhan. Sedangkan sumber karoten adalah sayuran berwarna hijau tua dan buah-buahan yang berwarna kuningjingga, seperti daun singkong, daun kacang, kangkung, bayam, kacang panjang, buncis, wortel, tomat, jagung kuning, papaya, mangga, nangka masak, dan jeruk. Minyak kelapa sawit yang berwarna merah kaya akan karoten (Adriani dan Wirjatmadi, 2014).

Data penelitian menunjukkan sebagian besar responden memiliki asupan zinc yang kurang dari angka kecukupan gizi yang dianjurkan. Hal ini menunjukkan bahwa semakin sedikit tingkat konsumsi zinc, maka akan semakin lambat pertumbuhan balita tersebut, karena mineral zinc sangat berperan dalam metabolism dan proses pertumbuhan dan perkembangan anak. Balita yang tingkat konsumsi zincnya lebih rendah mempunyai kemungkinan lebih besar untuk mengalami masalah pertumbuhan dari pada balita yang tingkat konsumsi zincnya lebih tinggi. Defisiensi zat gizi mikro seperti zinc apabila tidak diatasi sejak dini akan berdampak buruk dalam jangka panjang dan menghambat tumbuh kembang anak (Yustina dan Maria, 2014).

Hasil penelitian ini sejalan dengan penelitian yang dilakukan Kadek Dwika (2015) yang menunjukkan bahwa adanya hubungan antara asupan zinc dengan kejadian stunting. Hasil penelitian ini juga didukung oleh penelitian yang dilakukan oleh Priyono dkk (2015) tentang faktor resiko kejadian stunting pada anak balita yang menunjukkan bahwa adanya hubungan yang bermakna antara tingkat konsumsi zinc dengan kejadian stunting pada anak balita usia 12-36 bulan di wilayah kerja Puskesmas Randuagung Kabupaten Lumajang.

Zinc berfungsi untuk sintesis protein dan pertumbuhan. Kekurangan zinc memiliki dampak serius, seperti gangguan pertumbuhan dan diare (Fikawati dkk, 2017). Menurut Cunnane (1988), zinc memengaruhi aktivitas beberapa hormone seperti Human Growth Hormone (hormone pertumbuhan manusia). Beberapa penelitian terkait suplementasi zinc menunjukkan perbaikan pertumbuhan dan perbaikan system imun dalam mencegah terjadinya penyakit infeksi yang umum terjadi pada anak salah satunya yaitu diare. Defisiensi zinc dapat terjadi pada saat kurang gizi atau makanan yang dikonsumsi berkualitas rendah atau mempunyai tingkat ketersediaan zinc yang terbatas. Zinc merupakan kelompok elemen yang terdapat dalam tubuh, namun kandungan zinc yang terdapat dalam tubuh jumlahnya sangat kecil, oleh sebab itu diperlukan asupan zinc.

Berdasarkan analisis uji Fisher exact test menunjukkan bahwa terdapat hubungan yang bermakna antara asupan kalsium dengan kejadian stunting pada balita di wilayah kerja Puskesmas Gogagoman dengan nila $\rho<0,05$. Hasil penelitian ini sejalan dengan penelitian yang dilakukan Aprilitasari (2017) yang mengatakan bahwa tingkat konsumsi kalsium dalam kategori kurang lebih besar pada anak stunting daripada non stunting, hal ini menunjukkan bahwa terdapat 
hubungan antara asupan kalsium dengan kejadian stunting. Begitu juga dengan penelitian yang dilakukan Endah Mayang, dkk (2016) terhadap anak balita usia 24-59 bulan, didapat hasil bahwa adanya hubungan yang bermakna antara asupan kalsium dengan kejadian stunting.

Usia balita merupakan usia pertumbuhan yang membutuhkan asupan yang memadai salah satunya yaitu kalsium. Oleh karena itu kekurangan asupan kalsium pada anak balita dapat mempengaruhi proses pertumbuhannya dalam hal ini yaitu tinggi badan (Mardalena, 2017). Data penelitian menunjukkan sebagian besar responden memiliki asupan kalsium yang kurang dari AKG yang dianjurkan. Tubuh kita membutuhkan asupan kalsium yang memadai dari makanan sesuai dengan AKG yang berfungsi untuk memfalitsitasi pertumbuhan yang normal serta untuk mempertahankan pertumbuhan tulang. berdasarkan angka kecukupan gizi (AKG), kebutuhan kalsium untuk balita 1-3 tahun adalah $650 \mathrm{mg}$ /hari sedangkan untuk anak umur 4-6 tahun adalah $1000 \mathrm{mg} / \mathrm{hari}$.

Berdasarkan analisis uji Fisher's Exact test menunjukkan bahwa tidak terdapat hubungan yang bermakna antara asupan besi dengan kejadian stunting pada anak balita di wilayah kerja Puskesmas Gogagoman dengan nilai $\rho 0.02>0,05$. Hal ini juga didapat oleh Ermawati dan Nuryanto (2016) dalam penelitiannya tentang hubungan asupan protein, zinc, zat besi, dan riwayat penyakit infeksi dengan z-score TB/U pada balita yang menunjukkan bahwa tidak terdapat hubungan antara asupan besi terhadap z-score TB/U (kejadian stunting).

Namun dalam penelitian yang dilakukan Fatimah dan Wirjatmadi (2018) menunjukkan adanya hubungan antara asupan besi dengan kejadian stunting. Begitu juga dengan hasil penelitian yang dilakukan Nathania dan Merryana (2017), didapat hasil bahwa asupan besi anntara anak balita stunting lebih rendah dibandingkan dengan anak balita normal. Hal ini menunjukkan bahwa adanya hubungan yang bermakna antara asupan besi dengan kejadian stunting.

\section{KESIMPULAN}

Dari variabel penyakit infeksi (diare) dan asupan zat gizi (Protein, Vitamin A, Zinc, Kalsium, Besi) yang diteliti pada pada 41 sampel di wilayah kerja Puskesmas Gogagoman terkait kejadian stunting, yang mempunyai hubungan yang bermakna terhadap kejadian stunting antara lain penyakit infeksi (diare), asupan zinc, dan asupan kalsium. Sedangkan untuk asupan protein, vitamin A dan besi tidak adanya hubungan yang bermakna terhadap kejadian stunting. Stunting merupakan masalah gizi kronik yang dapat ditanggulangi secara early warning dengan pemantauan status gizi terutama tinggi badan secara rutin di posyandu sehingga bisa dideteksi dan diberikan intervensi dengan segera Stunting merupakan masalah gizi kronik yang dapat ditanggulangi secara early warning dengan pemantauan status gizi terutama tinggi badan secara rutin di posyandu sehingga bisa dideteksi dan diberikan intervensi dengan segera

\section{DAFTAR PUSTAKA}

Adriana, S Wirjatmadi,, B. (2014). Gizi dan Kesehatan Anak Balita. Kencana, Jakarta

Aprilitasari, A, H.2017. Perbedaan Asupan Zinc (Zn) dan Kalsium (Ca) Antara Anak Balita Stunting dan Non Stunting di Kelurahan Panularan Kota Surakarta. Naskah Publikasi.

Aridiyah, O, F Rohmawati, N Ririanty, M. 2015. Faktor-faktor yang Mempengaruhi Kejadian

Stunting pada Anak Balita di Wilayah Pedesaan dan Perkotaan. e- Jurnal Pustaka Kesehatan.3.(1:169).

Badan Penelitian dan Pengembangan Kesehatan Kementerian Kesehatan RI. (2013).

Riskesdas 2013. Jakarta.

http://www.depkes.go.id/resources/download/general/Hasil\%2520Riskesdas\%25202013.pdf . Diakses 5 April 2018. 
Cahya, I, A. 2014. Perbedaan Tingkat Asupan Energi, Protein dan Zat Gizi Mikro (Besi, Vitamin A, Seng) Antara Anak SD Stunting dan Non Stunting di Kecamatan Kartasura Kabupaten Sukoharjo. Naskah Publikasi.

Desyanti, C Nindya, T, S.2017; Hubungan Riwayat Penyakit Diare dan Praktik Higiene dengan Kejadian Stunting pada Balita Usia 24-59 Bulan di Wilayah Kerja Puskesmas Simolawang, Surabaya. DOI.1.(3:248-250).

Fatimah, H, S, N Wirjatmadi, B, R. 2018, Tingkat Kecukupan Vitamin A, Seng dan Zat Besi serta Frekuensi Infeksi pada Balita Stunting dan Non Stunting. Jurnal Media Gizi Indonesia. Vol 13, No 2.

Fikawati, S Syafiq, A \& Veratamala, A. (2017). Gizi Anak dan Remaja. Rajagrafindo Persada, Depok.

Grober, U. (2013). Mikronutrien. EGC, Jakarta.

Hariyati, N Rohmawati, N Ningtyas, W, F. 2016. Hubungan Antara Rlwayat Infeksi dan Tingkat Konsumsi dengan Kejadian Stunting pada Anak Usia 25-59 Bulan di Wilayah Kerja Puskesmas Kalisat Kabupaten Jember. Artikel IImiah Hasil Penelitian Mahasiswa.

Kementerian Desa, Pembangunan Daerah Tertinggal dan Transmigrasi. (2017). Buku Saku Desa dalam Penanganan Stunting. Jakarta. http://pdtu.bindola. com/uploads/ attachment/2018/03 /1522313956.pdf . Diakses 5 April 2018.

Kumaladewi, S Maryanto, S Pontang, S, G. 2016. Hubungan Asupan Energi, Protein, Vitamin A dan Seng $(\mathrm{Zn})$ dengan Kejadian Stunting pada Anak Usia Baru Sekolah di Kelurahan Candirejo. Jurnal Gizi dan Kesehatan JGK-vol.7, no.16

Kusudaryati, D, P, D.2017. 2017Pengaruh Suplementasi Zn Terhadap Kejadian Infeksi Pada Balita Stunting. JGI. Vol 5, No 2

Lestari, W Margawati, A Rahfilludin, M, Z. 2014. Faktor Resiko Stunting pada Anak Umur 6-24 bulan di Kecamatan Penanggalan Kota Subulussalam Provinsi Aceh. Jurnal Gizi Indonesia.3.(1:43)

Mardalena, I. (2017). Dasar-dasar IImu Gizi dalam Keperawatan. Pustaka Baru Press, Yogyakarta.

Mustaqiem, I Rinanda, T Suhanda, R.2015. Pengaruh Diare Terhadap Malnutrisi pada Balita di Puskesmas Batoh Banda Aceh . Sari Pediatri.18.(1:53).

Purba,R,B, Phembriah S. K, Anggriani Tabisi. 2019. Diare dan ASI Eksklusif dengan kejadian Stunting pada anak Usia 2 -3 Tahun di Wilayah Kerja Puskesmas Bailang. Jurnal Gizido Vol. 11 no 2.

Purnamasari, D. U (2018). Panduan Gizi dan Kesehatan Anak Sekolah. Penerbit Andi, Yogyakarta.

Setiawan, E Machmud, R Masrul. Faktor-faktor yang Berhubungan dengan Kejadian Stunting pada Anak Usia 24-59 Bulan di Wilayah Kerja Puskesmas Andalas Kecamatan Padang Timur Kota Padang Tahun 2018. Jurnal Kesehatan Andalas

Sari, E, M Juffrie, M Nurani, N Sitaresmi, M, N. Asupan Protein, Kalsium dan Fosfor pada Anak Stunting dan Tidak Stunting Usia 24-59 bulan. Jurnal Gizi Klinik Indonesia.12.(4:156).

Sundari, E Nuryanto. Hubungan Asupan Protein, Seng, Zat Besi dan Riwayat Penyakit Infeksi dengan Z-score TB/U pada Balita. Journal of Nutrition College.5.(4:527 528).

Taliwongso, F, Ch Manopo, J, I, Ch Umboh, A. Hubungan Stunting dengan Angka Kejadian Diare pada Siswa Sekolah Dasar di Kecamatan Tikala Manado. Jurnal e-Clinic.5.(2:247-248).

Tim Nasional Percepatan Penanggulangan Kemiskinan (TNP2K). (2017). 100 Kabupaten/Kota Prioritas Untuk Intervensi Anak Kerdil (Stunting). Jakarta. http://www.tnp2k.go.id/images/uploads/downloads/Buku\%2520Ringkasan\%2520Stunting1.pdf. Diakses 5 April 20108.

Triwibowo, C Pusphandani, M. E (2013). Kesehatan Lingkungan dan K3. Nuha Medika, Yogyakarta. 
Trihono Atmarita, Tjandrarini, D, H Irawati, A Utami, N, H Tejayanti, T dan Nurlinawati, I. (2015). Pendek (Stunting) di Indonesia, Masalah dan Solusinya. Badan Penelitian dan Pengembangan Kesehatan, Jakarta. http://pdgmi.org/wp-content/uploads/2016/08/stuntingdi-indonesia-A5-rev-7.pdf. Diakses 5 April 2018.

Wellina, F, W Kartasurya, M, I Rahfilludin, M, Z. Faktor Resiko Stunting pada Anak Umur 12-24 bulan. Jurnal Gizi Indonesia.5.(1:60).

WHO (2018). Equity Considerations for Achieving the Global Nutrition Targets 2025: Reducing Stunting in Children. World Health Organization, Geneva. http://www.who.int/nutrition/publications/reducing-stunting-children.equity/en/. $\quad$ Diakses tanggal 5 April 2018.

Zulkoni H, A. 2011. Parasitologi. Nuha Medika, Yogyakarta. 